EDUCATION

Research, Inovoration and Solutions on-line ${ }^{-(1)}$
PSYCHOLOGY

I+D+i
Electronic Journal of Research

in Educational Psychology

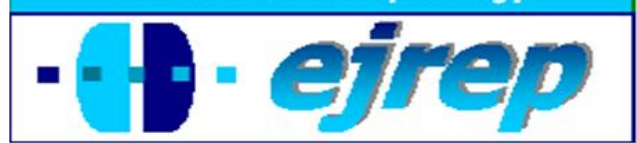

\title{
Career-self management and entrepreneurship: an experience with PhD students
}

\section{Joana Carneiro Pinto ${ }^{1}$, Maria do Céu Taveira ${ }^{2}$, \& Elisabete $\mathbf{S a ́}^{3}$}

\author{
${ }^{1}$ School of Psychology, University of Minho, Braga \\ ${ }^{2}$ School of Psychology, University of Minho, Braga \\ ${ }^{3}$ School of Economics and Management, University of Minho, Braga
}

\section{Portugal}

Correspondence: Joana Carneiro Pinto. Centre of Research in Psychology, Campus of Gualtar, University of Minho, 4710-057 Braga, Portugal. e-mail: joanacpinto_@hotmail.com

(C Education \& Psychology I+D+i and Editorial EOS (Spain) 


\section{Abstract}

Introduction. This study presents an experience developed with $\mathrm{PhD}$ students aimed to analyze the extent to which career self-management should be approached along with entrepreneurship issues to promote students' career development.

Method. An intervention group who attended a Career Self-Management Seminar (EG1), a comparison group who attended the CSMS followed by a Seminar on Entrepreneurship (EG2), and a control group (CG) were compared, in three different moments (pre-test, posttest, and follow-up).

Results. Results at an intra and inter-group level indicate that the EG1 and the EG2 significantly increased the extent of self-exploration, the intended-systematic exploration, and the amount of acquired information over time, and also their concerns related to holding and updating their careers. According to the longitudinal research plan, the EG1 participants benefited most of this career intervention.

Discussion and Conclusion. The results suggest the effectiveness of the career seminar in most of the career development measures, particularly in comparison with the nonintervention. Implications are drawn to the development of career services and interventions that promote a reflection about entrepreneurship as a career path.

Keywords: career self-management, entrepreneurship, PhD students, seminar. 


\section{Autogestión de la carrera profesional y el emprendimien- to: una experiencia con estudiantes de doctorado.}

\section{Resumen}

Introducción. Este estudio presenta un experimento desarrollado con estudiantes de doctorado, con el fin de analizar el grado en que la gestión personal de la carrera debe ser trabajada junto con temas de la iniciativa empresarial, para promover el desarrollo profesional de los estudiantes.

Método. Un grupo de intervención que asistió al Seminario de Gestión Personal de la Carrera (EG1), un grupo de comparación que asistiu a la CSMS seguido de un seminario sobre el espíritu empresarial (EG2), y un grupo control (CG) fueron comparados, en tres momentos diferentes (pre-test, pos-test, y seguimiento).

Resultados. Resultados a nivel intra e inter-grupal indican que el EG1 y EG2 presentan un aumento significativo en la auto-exploración, la exploración sistemática-intencional, y la cantidad de información adquirida a través del tiempo, y también sus preocupaciones relacionadas con la capacidade de mantenimiento y actualización de sus carreras. De acuerdo con el plan de investigación longitudinal, los participantes de EG1 fueron os que más beneficiaron de esta intervención en la carrera.

Discusión y conclusión. Los resultados sugieren la efectividad del seminario de la carrera en la mayor parte de las medidas de desarrollo profesional, especialmente en comparación con la no intervención. Consecuencias son extraídas por el desarrollo de servicios y intervenciones profesionales que promueven una reflexión sobre el espíritu empresarial como una carrera.

Palabras Clave: gestión personal de la carrera, espíritu empresarial, estudiantes de doctorado, seminario.

Recibido: 10/12/12 Aceptación inicial: 09/04/12 Aceptación final: 26/06/12 


\section{Introduction}

In recent years, the world has witnessed dramatic economic, political and social changes, with deep repercussions in the current career paths (e.g., Appelbaum, Ayre, \& Shapiro, 2002; Blustein, 2006; Martínez-Vicente, 2007; Pinto, 2010; Rafael, 2007). An analysis of the main European statistics (Eurostat, 2010; OECD, 2010) in the field of education and employability, indicates that it is increasingly vast the number of higher education students that complete their graduate and post-graduate studies each year. In 2007, this number was close to four million graduates, considering the Europe of 27. This is the educational level that has the highest employment rate (84\% in 2008) when compared with other levels, namely, the Elementary and Secondary Education. However, the waiting period for a first job is also increasing. Data from OECD (2010) show that the majority of young adults, who complete their studies each year and search for a first job opportunity, take an average of seven months to achieve it.

In addition, it should be noted that the career, in a more traditional sense, that is, linear, rigid and unidirectional, no longer exists (Baruch, 2004; Gilbert, Sohi \& McEachern, 2008). Currently, there are only employment opportunities that last just long enough for the employer and/or their employees meet their interests and needs (Atkinson, 2002; Pinto, 2010). On the one hand, the organization aims to ensure that, when hiring a worker, it will buy his/her effort, productivity and competitiveness. On the other hand, the worker wants to ensure that, when accessing to the organization, he/she will be involved in opportunities of learning, training and development that will contribute to the increase of the capital career, and consequently, to the increase of his/her value in the labor market (Dutra, Veloso, Fischer, \& Nakata, 2009). For this reason, it is expected that a young adult, during his/her work life, get involved on average in eleven different jobs (Bureau of Labor Statistics, 2010). It is important to emphasize this is contrary to the expectations that young graduates have when making the transition from the university to the job market. A study conducted recently by McKeown and Lindorff (2011), with young Australian graduates, indicated that they continue to consider there is a direct correspondence between getting a college degree and getting a job. Moreover, despite the high competitiveness and their reduced professional experience, they still hope to attain stability, security and high remuneration in their future job. 
This discrepancy between the expectations of young graduates and the actual circumstances of the labor market should not call into question their involvement in their graduate and postgraduate studies. The education and employability statistics presented above show that it is worth a focus on the education and training in order to attain skilled manpower. Qualified young people not only ensure higher levels of personal and professional satisfaction and success, but also contribute to the economic and social development of their country. Moreover, due to the lack of employment opportunities, a small percentage (15\%) of young people has focused on creating opportunities through self-employment (OECD, 2003; in Peel \& Inkson, 2004), which in the medium and long term contributes to reduce the unemployment rates and to increase the living conditions in their countries. However, it turns out, in general, that people still think about their careers in a very traditional way. Also, they do not feel proficient to make an effective career management, in a career that has become more protean, intelligent, and boundaryless (Sarjoo \& Barry, 2011). And, they rarely address entrepreneurship as a career option (Benítez \& Pérez, 2008; Peel \& Inkson, 2004; Henderson \& Robertson, 1999). Thus, the following research paper addresses the need for an effective career management to be approached along with entrepreneurship issues, in order to promote student's career development in the current societal circumstances.

\section{About career self-management}

Career self-management concerns a cyclical, systematic, and recursive process, of decision-making, and problem solving, in the career context (Greenhaus, Callanan, \& Godshalk, 2010; Pinto \& Taveira, 2010). This process, generally, comprises four main steps: (a) selfexploration and environment exploration, that is, the ability to identify and clarify personal and professional interests, life values and skills, and also, to recognize educative, formative, and professional options, (b) development of specific and realistic life and career goals, in the short, medium and long term, (c) design and implementation of action plans, intended to encourage the achievement of those life/career goals, and (d) obtaining feedback, that is, monitoring and evaluating the degree of progression towards the desired life/career goals.

In general, it is assumed that organizations should take responsibility to support individuals in the task of career management (e.g., Baruch, 2004). However, whether or not the organizations collaborate with their employees, it is now widely considered to be individuals' responsibility to take control and to self-manage their careers (Cappellen \& Janssens, 2008; Van Viannen, Del Pater \& Preenen, 2008). This question of who has to take responsibility for 
this process has led to many discussions about the boundaries between career selfmanagement and organizational career management (e.g. De Vos, Dewettinck, \& Buyens, 2009, 2006; Sturges, Guest, Conway, \& Davey, 2002).

A literature review in this area makes clear that the career self-management is the process by which the individual takes full responsibility for being proactive in order to engage in self-development behaviors, activities and strategies that will enable him/her to acquire the necessary strategies to make career decisions and to solve career problems. On the other hand, organizational career management is the process by which organizations seek to provide opportunities and activities to individuals that will enable them to acquire the necessary strategies to make career decisions and to solve career problems. However, it should be noted that this support from organizations exists only during the period in which the employee remains within its structures. Thus, it is increasingly argued that the responsibility for this process is based on workers, since their professional trajectories are marked by more or less prolonged periods of unemployment. Several studies have shown that both career management processes are complementary, and their conjoint implementation is often associated with career outcomes, as broad as, more organizational commitment (De Vos et al., 2009), more career satisfaction (Murphy \& Ensher, 2001; Neault, 2002), more subjective career success (De Vos et al., 2009), and less turnover (Sturges, Conway \& Liefooghe, 2008). However, despite being highly beneficial the engagement in career management activities to both individuals and organizations, it is still scarce the societies investment in this area.

The development of career intervention programs, which aim to help participants to acquire, train, and develop career self-management skills, may assist individuals in the exploration and decision making related to an entrepreneurial career, and also, to help them in its effective design, construction, and development. Most individuals do not know what career self-management is, nor hold the necessary skills to be able to manage properly his/her career. Thus, the widespread idea that the young, future entrepreneurs, on leaving university, are highly qualified individuals, with scientific expertise, very focused on their careers and, therefore, they require no support for the management of their career, makes no more sense nowadays (Sarjoo \& Barry, 2011). Consequently, the provision of services to support the development of career self-management skills, coupled with the introduction of entrepreneurship courses in different programs, at undergraduate and postgraduate level, is particularly relevant in higher education. It is in the university context, for example, that these young people can 
acquire, train, and develop several personal and managerial capabilities and competences (Lucas, 2007; Martínez-Vicente, 2007). These skills are significantly associated with a higher probability of being able to identify and pursuit opportunities and entrepreneurs with these capabilities are more likely to be able to convert an idea into a business opportunity (Ucbasaran et al, 2007). It is also in this context that specialized and differentiated knowledge is continuously produced and has, in some cases, high commercial potential which is not successfully explored. In many cases, this potential is not even recognised, since the entrepreneurial option is not considered.

\section{About entrepreneurship}

The present harsh employability conditions make entrepreneurship to assume an increased importance, since it is acknowledged that entrepreneurial firms can make a higher contribution to job creation in relation to their incumbent counterparts (Van Praag \& Versloot, 2007). When based on knowledge that fosters innovation, which is generally known as opportunity entrepreneurship, entrepreneurial activity is also proven to be positively related to economic growth (Acs, 2006; Carree \& Turik, 2003; Salgado-Banda, 2007). Entrepreneurs are actively involved in the tremendously important and noble process of changing the world, hopefully, making it better (Greenhaus, Callanan, \& Godshalk, 2010). For those reasons, entrepreneurship has gained prominence in recent years, not only at the political level, but also within the academic field, where it has been attracting increasing interest of researchers (Cooper, 2003). Nevertheless, the development of the area may be being undermined by the fact that neither the research boundaries are fully defined nor there is a general agreement on the very definition of entrepreneurship (Busenitz et al., 2003; Sánchez, 2011; Wiklund et al. 2010). In particular, the question why some people decide to adopt entrepreneurial paths, while others do not, remains open. Some research suggests that entrepreneurs have distinctive personalities that influence their choices (e.g. Rauch \& Frese, 2007a, 2007b). However, the attempts to unveil the profile of the entrepreneur yielded inconclusive and generally disappointing results, giving rise to some criticism (Gartner, 1989). As Baron (1998, p. 275) notes: "contrary to what informal observation suggests, entrepreneurs do not appear to differ greatly from non entrepreneurs with respect to various aspects of personality". Alternatively, other researchers adopt a cognitive perspective, seeking to understand why some people, but not others, become entrepreneurs by exploring the entrepreneurial mindset, and the cognitive mechanisms trough which information is acquired, stored, transformed and used by the entrepreneurs (Baron, 2004; Mitchell et al., 2002; Sánchez et al., 2011). 
While it may be difficult to discover the characteristics of the entrepreneurs and to deeply understand how they think and make decisions, there are several factors that are known to influence the entrepreneurial career option. A summary of the main factors identified in literature (e.g., Feldman \& Bolino, 2000; Greenhaus, Callanan, \& Godshalk, 2010; Wilson, Kickul, \& Marlin, 2007) as contributing to the individuals engagement in this type of career trajectories, indicates the existence of two major groups: personal factors, such as, selfefficacy beliefs, desire for autonomy and independence, need for achievement, desire of control, tolerance for ambiguity, and risk-taking propensity; and the demographic and environmental factors (including economic and social factors), such as, prior work experience, work dissatisfaction, family support, presence of role-models, and the existence of favourable business conditions.

However, it is clear that the presence of these variables favours, but does not guarantee, the involvement of individuals in entrepreneurial careers. In fact, despite the diversity of personal, economic and social benefits that are associated with the development of an entrepreneurial career, entrepreneurship is not very often considered when deciding one's career (Henderson \& Robertson, 1999).

\section{Aim of the study and hypotheses}

This study represents an applied experience aimed to assess the outcomes of the Career Self-Management Seminar (CSMS). This program was developed to support PhD students in their self-exploration, and the exploration about academic training and professional opportunities, in the development of life/career goals, as well as, in the implementation of action plans that promote the attainment of those goals, by developing and maintaining a positive outlook on the future. Participants were organized in three distinct groups, assessed in three different moments. Both EG1 and EG2 attended the CSMS, but the EG2 also attended the Seminar on Entrepreneurship (SENT). The CG didn't attend any career intervention during this period. It is expected that the both experimental groups demonstrate significantly differences in the career exploration and the concern dimensions, in comparison to nonintervention. It is also assumed that the attendance of the SENT contributes to the improvement and maintenance, over time, of the career results in the EG2, in comparison to the EG1. 


\section{Method}

\section{Participants}

Participants were $18 \mathrm{PhD}$ students from the University of Minho, a Portuguese public higher education institution. These participants, 12 women and 6 men, aged between 23 and 49 years old $(M=33 ; S D=8.67)$, were developing their research projects in the following main research areas: Social and Behavioural Sciences $(n=14)$, Engineering and Technology $(n=2)$, and Natural Sciences $(n=2)$. They had an average working time of 119.39 months ( $\mathrm{SD}=111.77$; Min=2; Max=372), an average time in the same enterprise/university of 44.33 months ( $\mathrm{SD}=41.6$; $\mathrm{Min}=5$; $\mathrm{Max}=132$ ), and an average time as $\mathrm{PhD}$ students of 21.17 months $(\mathrm{SD}=16.86$; $\mathrm{Min}=5 ; \mathrm{Max}=72)$. Five participants were anticipating a change in their current occupational category within a year.

Participants were organized into three different intervention groups: an experimental group (EG1, $n=5)$, a comparison group (EG2, $n=7)$, and a control group $(C G, n=6)$, whose socio-demographic characteristics are detailed in Table 1.

\section{Instruments}

The Career Exploration Survey, CES (Stumpf, Colarelli \& Hartman, 1983; adapt. by Taveira, 1997) is a self-report questionnaire which assesses the cognitive, behavioural, and emotional dimensions related to the career exploration process, as conceived in the hierarchical and multidimensional model of Stumpf, Colarelli and Hartman (1983). In the Portuguese version, it consists of 54 items, with five response categories in questions 1 to 43 , and seven response categories in questions 44 to 53, (in which 1 means "very little", and 5 or 7 means "a great deal"). These items are organized into twelve distinct subscales: five beliefs (Employment Outlook, Certainty of Outcomes, External Search Instrumentality, Internal Search Instrumentality and Importance of Preferred Position), four behaviours (Extent of Environment Exploration, Extent of Self-Exploration, Intended-Systematic Exploration and Amount of Acquired Information), and three reactions to career exploration (Satisfaction with Information, Exploration Stress and Decision Stress). The $54^{\text {th }}$ item, using an open response format, stimulates individuals to specify the number of explored career domains. Examples of items are: "How certain are you that you will begin work upon graduation, at the specific enterprise/company you are interested"? (item 22); "How important is it for you at this time to work at a specific company?" (item 40). Internal consistency of these subscales ranges from 
Table 1. Participants' social-demographic characterization

\begin{tabular}{|c|c|c|c|c|c|c|c|c|c|c|c|c|c|c|c|c|}
\hline \multirow{2}{*}{ Sample } & \multirow[t]{2}{*}{$\mathbf{N}$} & \multicolumn{2}{|c|}{ Sex } & \multicolumn{3}{|c|}{ Age } & \multicolumn{3}{|c|}{$\begin{array}{l}\text { Average working time } \\
\text { (months) }\end{array}$} & \multicolumn{3}{|c|}{$\begin{array}{l}\text { Average time in uni- } \\
\text { versity/enterprise } \\
\text { (months) }\end{array}$} & \multicolumn{3}{|c|}{$\begin{array}{l}\text { Average time in func- } \\
\text { tion (months) }\end{array}$} & \multirow{2}{*}{$\begin{array}{l}\text { Change } \\
\text { in func- } \\
\text { tion } \\
\text { Yes }(\%)\end{array}$} \\
\hline & & F (\%) & M (\%) & Mean & SD & $\begin{array}{l}\text { Min- } \\
\text { Max }\end{array}$ & Mean & SD & $\begin{array}{l}\text { Min- } \\
\text { Max }\end{array}$ & Mean & SD & $\begin{array}{l}\text { Min- } \\
\text { Max }\end{array}$ & Mean & SD & $\begin{array}{l}\text { Min- } \\
\text { Max }\end{array}$ & \\
\hline EG1 & 5 & $2(40 \%)$ & $3(60 \%)$ & 37.8 & (10.05) & $\begin{array}{c}25- \\
49 \\
\end{array}$ & 211.2 & (152.41) & $\begin{array}{l}24- \\
372 \\
\end{array}$ & 12.6 & $(6.84)$ & $6-24$ & 12.6 & $(6.84)$ & $6-24$ & 0 \\
\hline EG2 & 7 & $\begin{array}{c}7 \\
(100 \%)\end{array}$ & 0 & 32.14 & (7.69) & $\begin{array}{c}23- \\
48\end{array}$ & 91.14 & $(45.75)$ & $\begin{array}{c}2- \\
144\end{array}$ & 6 & (45.03) & $\begin{array}{c}6- \\
132\end{array}$ & 26.57 & $(21.31)$ & $6-72$ & $\begin{array}{c}1 \\
(14.3 \%)\end{array}$ \\
\hline CG & 6 & $3(50 \%)$ & $3(50 \%)$ & 30 & $(8.32)$ & $\begin{array}{c}24- \\
46\end{array}$ & 75.83 & (97.76) & $\begin{array}{c}5- \\
264\end{array}$ & 45.5 & (41.81) & $5-96$ & 22 & (16.41) & $5-48$ & $\begin{array}{c}4 \\
(66.7 \%) \\
\end{array}$ \\
\hline Total & 18 & $\begin{array}{c}12 \\
(66.7 \%)\end{array}$ & $\begin{array}{c}6 \\
(33.3 \%)\end{array}$ & 33 & $(8.67)$ & $\begin{array}{c}23- \\
49\end{array}$ & 119.39 & (111.77) & $\begin{array}{c}2- \\
372\end{array}$ & 44.33 & (41.6) & $\begin{array}{c}5- \\
132\end{array}$ & 21.17 & (16.86) & $5-72$ & $\begin{array}{c}5 \\
(27.8 \%)\end{array}$ \\
\hline
\end{tabular}


.60 to .89 in recent studies developed with university (Soares, 1998) and non-university students (Silva \& Taveira, 2010).

The Adult Career Concerns Inventory, ACCI (Super, Thompson \& Lindeman, 1988; adapt. by Duarte, 1999) is a self-report questionnaire that assesses participants' type of concern related to the career development tasks, as conceived in the Career Development Model of Donald Super (Super, et al., 1988, p.13; Super, 1990). In its Portuguese version, it consists of 61 items or statements, 60 of them using a five-point Likert type response format (in which 1 means "little concern" and 5 means "great concern"). These items are organized into four scales and twelve subscales, namely: Exploration (Crystallization, Specification, and Implementation), Establishment (Stabilizing, Consolidating, and Advancing), Maintenance (Holding, Updating, and Innovating) and Disengagement (Deceleration, Retirement Planning, and Retirement Living). The $61^{\text {st }}$ item asks participants to select, from a set of five different scenarios concerning a career change, the one that best describes their current career projects. Examples of items are: "To what extent do you have these concerns at this stage of your career": "Decide what to do for a living" (item2); "Choose a job that really satisfies me" (item 10). Cronbach's alpha values range from .73 to .96 in studies developed with Portuguese adult workers (Duarte, 1993; Rafael, 2001).

\section{Procedure}

The Career Self-Management Seminar is a psychological intervention which aims to promote the career management skills in young adults engaged in scientific research projects (CSMS). It comprises six sessions of 120 minutes each, on a weekly basis, along which it aims to (a) introduce the participants in the process of the career self-management, (b) foster the self-knowledge, the knowledge about the opportunities for advanced training, for obtaining and creating a job, as well as, for planning and deciding about personal career, and (c) support the consolidation and generalization of these learning to other life domains. This intervention was implemented by a doctoral student attending the Doctoral Program in Vocational Psychology, at the School of Psychology, University of Minho, and is structured as follows: Session 0 - Start: presentation of the seminar's themes, goals and structure, as well as, the career self-management concept and theoretical model; Session 1 - Career Paths: exploration of the personal life history, and framework of the doctoral or research work in the broader life project; Session 2 - Recognition and Validation of Career Skills: exploration and development of aspirations, skills, interests and desired lifestyles; Session 3 - Establishment 
of a Life Project: development of future life projects through the conciliation of personal, academic, professional and social goals; Session 4 - Self-Management of the Life Project: development of future life projects by deepening the themes of job creation and job search; and, Session 5 - End: development and maintenance of a positive view of the future and conclusion of the career intervention process.

In turn, the Seminar on Entrepreneurship (SENT) corresponds to a workshop which aims to promote the idea that almost all people can realize their potential through an entrepreneurial path. It consists of five sessions of 120 minutes each, on a weekly basis, along which it aims to (a) increase participants' awareness about the concept of entrepreneurship and its importance for development, (b) clarify its relevance for the exploration of knowledge developed in the context of the various research areas, and, (c) support the recognition and exploration and of entrepreneurial opportunities. This workshop was implemented by a professor from the School of Economics and Management, University of Minho and is structured as follows: Session 1 - Approach to the concept of entrepreneurship and its importance: clarification of the entrepreneurship concept and its contrast with the reductive idea of business management; and also introduction to the alternative applications of the entrepreneurial mindset; Session 2 - Creativity and Ideation: application of several creativity and idea generation techniques intending to identify and explore business opportunities; Session 3 - Business Model Development: planning of the architecture of the business, connecting the business idea to a market need; Session 4 - Environment and competitive strategy: analyses of the several factors potentially affecting the business success and identification of the competitive edge; Session 5 - Marketing and Finance: devising of the market entry strategy and analysis of some brief figures in order to get a general idea of the economic and financial viability of the business.

Participants in the experimental groups 1 and 2 were recruited for this research through the dissemination of advertising about the CSMS on both campuses of the University of Minho (Portugal). Participants in both groups attended for six consecutive weeks the CSMS, but the experimental group 2 also agreed to attend the SENT, during a period of five weeks. The control group was recruited by e-mail, by sending an informative text about the goals and characteristics of this research. Participants in this group did not attend any intervention in the time period considered. 
Participants from all groups were administered the instruments to assess the career exploration levels and the type of career concerns, in three distinct moments in time, corresponding to the pre-test, the post-test, and the follow-up, with a five-week interval between each. The pre-test and post-test were completed by the participants at the experimental groups 1 and 2 in the sessions 0 and 5 of the CSMS, respectively, and by the participants at the control group at equivalent time periods. The follow-up was completed by all groups, five weeks after the post-test, which corresponds, in the experimental group 1 to a period of five weeks after the completion of the CSMS, and in the experimental group 2 one week after the completion of SENT.

\section{Data Analysis}

Data were processed using the statistical software PASW (Predictive Analytics Software), version 18 for Windows. Descriptive analyzes were performed for the participants' socio-demographic characteristics, and their outcomes related to the career exploration and career concern subscales. The effects of the intervention on the inter-group level were evaluated using the Kruskal Wallis test and the Mann-Whitney test, and the effects on the intragroup level were evaluated by the Friedman test and Wilcoxon tests. In all tests were considered statistically significant the results with a $\mathrm{p}$ value less than or equal to $.05(\mathrm{p} \leq .05)$. The exception was found only in situations where the application of Kruskal Wallis $\mathrm{H}$ test and Friedman was followed by the application of the Mann-Whitney and Wilcoxon test, respectively. In these particular cases, it was necessary to apply the Bonferroni's correction.

\section{Results}

\section{Descriptive outcomes}

The results of the descriptive analysis at an intra-group leve are presented in Table 2. The experimental group 1 had, at pre-test, results above the mean scores in three subscales from the CES, specifically, Internal Search Instrumentality, Amount of Acquired Information, and Satisfaction with Information. In the post-test and follow-up moments, there were results above the mean score in all subscales mentioned above, but also in the Employment Outlook, External Search Instrumentality, Importance of Preferred Position, Extent of Environment Exploration, and Extent of Self Exploration. In what concerns to the ACCI, there have been found, at the pre-intervention, results above the mean score in nine of the twelve subscales, namely: Specification, Implementation, Stabilizing, Consolidating, Advancing, Maintaining, Updating, Innovating, and Reform Living. At the post-test, there have been some changes, 
reaching above the mean score only the subscales related to Consolidating and Reform. Also at the follow-up, there has been a new pattern of results, with values above the mean score on the subscales Implementation, Stabilizing, Consolidating, Advancing, Maintaining, Updating and Innovating.

The experimental group 2 achieved, at pre-test, results above the mean score on the Employment Outlook, External Search Instrumentality, Internal Search Instrumentality, Importance of Preferred Position, Intended-Systematic Exploration, Amount of Acquired Information, and Satisfaction with Information subscales, from the CES. At the post-test there was a general tendency to maintain these results, with the exception of the Intended-Systematic Exploration and Certainty of Outcomes subscales, which have seen their mean scores decreased and increased, respectively. In what concerns the follow-up, results were found above the mean scores on the Employment Outlook, Certainty of Outcomes, Importance of Preferred Position, Extent of Environment Exploration, Extent of Self-Exploration, IntendedSystematic Exploration, Amount of Acquired Information, and Satisfaction with Information subscales. The analysis of the ACCI, in turn, indicated results above the mean score, at the pre and post-test, in the Implementation, Stabilizing, Consolidating, Advancing, Holding, Updating and Innovating subscales. Regarding to the follow-up, of the previously mentioned subscales, only the Innovating subscale did not reach a higher result than the mean score. In contrast, the Reform Living subscale exceeded this value.

The control group presented, both at the CES and the ACCI, results very similar between the three assessment periods that have been considered. At the first questionnaire, there are results above the mean score on the External Instrumentality Search, Internal Search Instrumentality, Importance of Preferred Position, and Satisfaction with Information subscales, at all moments in time. In addition, the Amount of Acquired Information subscale, at the posttest, and the Extent of Self-Exploration, and the Amount of Acquired Information subscales, at the follow-up, scored above its mean score. On the second questionnaire, scored above the mean score, at the three assessment moments, the Implementation, Stabilizing, Consolidating, Advancing, Holding, Updating, and Innovating subscales. Additionally, at the pre-test, also scored above the mean scores the Retirement Planning and Retirement Living subscales, and at the follow-up, the Crystallization, Specification, Retirement Planning, and Retirement Living subscales. 
Table 2. Career Exploration and Career Concerns: descriptive outcomes ( $n=18)$

\begin{tabular}{|c|c|c|c|c|c|c|c|c|c|c|c|}
\hline \multirow[b]{2}{*}{ Questionnaire } & \multirow[b]{2}{*}{ Subscales } & \multirow[b]{2}{*}{$\begin{array}{l}\text { Mean } \\
\text { score }\end{array}$} & \multicolumn{3}{|c|}{ EG1 (n=5) } & \multicolumn{3}{|c|}{ EG2 (n=7) } & \multicolumn{3}{|c|}{ CG $(n=6)$} \\
\hline & & & $\begin{array}{c}\text { Pre-test } \\
\text { Mean } \pm \text { SD }\end{array}$ & $\begin{array}{c}\text { Post-test } \\
\text { Mean } \pm \text { SD }\end{array}$ & $\begin{array}{l}\text { Follow-up } \\
\text { Mean } \pm \text { SD }\end{array}$ & $\begin{array}{c}\text { Pre-test } \\
\text { Mean } \pm \text { SD }\end{array}$ & $\begin{array}{c}\text { Post-test } \\
\text { Mean } \pm \text { SD }\end{array}$ & $\begin{array}{l}\text { Follow-up } \\
\text { Mean } \pm \text { SD }\end{array}$ & $\begin{array}{c}\text { Pre-test } \\
\text { Mean } \pm \text { SD }\end{array}$ & $\begin{array}{c}\text { Post-test } \\
\text { Mean } \pm \text { SD }\end{array}$ & $\begin{array}{l}\text { Follow-up } \\
\text { Mean } \pm \text { SD }\end{array}$ \\
\hline \multirow{12}{*}{ CES } & Employment Outlook & 9 & $7.75 \pm 2.99$ & $9.25 \pm 1.89$ & $9.25 \pm 1.26$ & $10.43 \pm 2.15$ & $10.43 \pm 2.15$ & $10.29 \pm 2.81$ & $6.83 \pm 3.37$ & $8.5 \pm 3.67$ & $8 \pm 2.97$ \\
\hline & Certainty of Outcomes & 9 & $7.25 \pm 3.5$ & $8.75 \pm 1.26$ & $8 \pm 3.46$ & $7.43 \pm 2.94$ & $9.57 \pm 4.16$ & $9.43 \pm 3.21$ & $7.67 \pm 4.41$ & $6.17 \pm 5.15$ & $7.5 \pm 4.72$ \\
\hline & External Search Instrumentality & 12 & $11.75 \pm 4.79$ & $13.5 \pm 3.42$ & $14.25 \pm 4.27$ & $12.57 \pm 3.95$ & $14.57 \pm 4.35$ & $11 \pm 3.79$ & $15 \pm 2.61$ & $13.17 \pm 3.97$ & $12.83 \pm 4.58$ \\
\hline & Internal Search Instrumentality & 30 & $30.75 \pm 5.38$ & $35.5 \pm 3.7$ & $34 \pm 6.06$ & $32.86 \pm 7.76$ & $39.57 \pm 5.74$ & $29 \pm 9.49$ & $35.33 \pm 3.45$ & $39 \pm 6.33$ & $32.33 \pm 5.69$ \\
\hline & Importance of Preferred Position & 9 & $7.5 \pm 1$ & $9 \pm 2.83$ & $9.5 \pm 1$ & $10.43 \pm 3.21$ & $11.71 \pm 1.98$ & $11.86 \pm 2.19$ & $9.17 \pm 3.25$ & $10.5 \pm 4.32$ & $9.17 \pm 3.82$ \\
\hline & Extent of Environment Exploration & 12 & $10.75 \pm 5.44$ & $13 \pm 2.16$ & $13.75 \pm 2.06$ & $10.71 \pm 4.79$ & $11.14 \pm 5.21$ & $12.29 \pm 4.27$ & $9.33 \pm 3.98$ & $11 \pm 3.63$ & $10 \pm 4.2$ \\
\hline & Extent of Self- Exploration & 15 & $13.75 \pm 3.86$ & $20.75 \pm 3.5$ & $15.5 \pm 1.29$ & $13.86 \pm 6.31$ & $14.57 \pm 3.6$ & $16.43 \pm 2.99$ & $14.33 \pm 4.59$ & $14.67 \pm 5.82$ & $15 \pm 6.16$ \\
\hline & Intended-Systematic Exploration & 6 & $4 \pm 1.41$ & $4.5 \pm 1.9$ & $5 \pm 2.16$ & $6.71 \pm 2.14$ & $5.14 \pm 2.34$ & $6.43 \pm 2.22$ & $4.83 \pm 1.94$ & $5.33 \pm 2.42$ & $5 \pm 1.79$ \\
\hline & Amount of Acquired Information & 9 & $9.5 \pm 1.73$ & $11.5 \pm 2.52$ & $10.75 \pm 1.25$ & $11.43 \pm 1.9$ & $11.14 \pm 1.95$ & $11.57 \pm 1.72$ & $8.67 \pm 1.86$ & $10.5 \pm 2.07$ & $11.67 \pm 2.34$ \\
\hline & Satisfaction with Information & 9 & $9.25 \pm 1.71$ & $11.25 \pm 2.06$ & $10 \pm 2.16$ & $10.86 \pm 1.07$ & $11.14 \pm 1.95$ & $12.14 \pm 1.46$ & $9.5 \pm 1.87$ & $9.67 \pm 2.07$ & $11.33 \pm 1.86$ \\
\hline & Exploration Stress & 16 & $11.75 \pm 3.86$ & $13 \pm 4.4$ & $13.5 \pm 3.42$ & $12 \pm 5.35$ & $14.71 \pm 5.41$ & $12.57 \pm 3.46$ & $11.33 \pm 2.07$ & $12.5 \pm 5.13$ & $11.5 \pm 4.97$ \\
\hline & Decision Stress & 20 & $16.5 \pm 8.85$ & $15.25 \pm .99$ & $16.5 \pm 6.95$ & $15 \pm 7.77$ & $16.86 \pm 6.59$ & $15.86 \pm 6.27$ & $16.17 \pm 5.67$ & $18.67 \pm 8.34$ & $14.33 \pm 6.68$ \\
\hline \multirow{12}{*}{ ACCI } & Crystallization & 15 & $14.5 \pm 3.7$ & $10.5 \pm 4.2$ & $12.25 \pm 4.86$ & $11.86 \pm 5.81$ & $11.57 \pm 5.22$ & $12.29 \pm 6.45$ & $12.83 \pm 4.45$ & $16 \pm 3.41$ & $14.5 \pm 4.04$ \\
\hline & Specification & 15 & $15 \pm 3.37$ & $11.5 \pm 3.42$ & $13 \pm 4.16$ & $13.86 \pm 5.98$ & $13.86 \pm 4.45$ & $13 \pm 6.35$ & $12.5 \pm 4.85$ & $16.67 \pm 6.06$ & $15.17 \pm 6.18$ \\
\hline & Implementation & 15 & $17 \pm 4.08$ & $14.25 \pm 4.57$ & $15.5 \pm 3.11$ & $16.14 \pm 5.46$ & $15.86 \pm 5.9$ & $17.29 \pm 5.88$ & $17.33 \pm 1.75$ & $16.33 \pm 3.56$ & $17.67 \pm 2.94$ \\
\hline & Stabilizing & 15 & $17.75 \pm 5.5$ & $14.75 \pm 6.29$ & $17 \pm 7.16$ & $16.29 \pm 6.32$ & $18.86 \pm 5.21$ & $19 \pm 5.54$ & $20.5 \pm 2.26$ & $19.33 \pm 3.27$ & $20.33 \pm 2.07$ \\
\hline & Consolidating & 15 & $21.25 \pm 3.86$ & $16.5 \pm 5.07$ & $18 \pm 4$ & $15.86 \pm 5.46$ & $19.57 \pm 3.99$ & $20 \pm 5.13$ & $21.33 \pm 4.27$ & $18.83 \pm 2.64$ & $20.5 \pm 3.51$ \\
\hline & Advancing & 15 & $18.75 \pm 5.91$ & $13.75 \pm 8.77$ & $15.75 \pm 3.86$ & $17.43 \pm 4.72$ & $20.14 \pm 4.6$ & $19.29 \pm 3.45$ & $19.17 \pm 4.92$ & $18.17 \pm 4.36$ & $17.33 \pm 4.76$ \\
\hline & Holding & 15 & $17.25 \pm 3.59$ & $12.25 \pm 2.87$ & $15.75 \pm 1.71$ & $16.71 \pm 4.82$ & $19.29 \pm 4.64$ & $20 \pm 3.61$ & $19.83 \pm 1.17$ & $19.17 \pm 3.49$ & $19.33 \pm 3.01$ \\
\hline & Updating & 15 & $19.5 \pm 2.38$ & $14 \pm 5.89$ & $18.25 \pm 2.98$ & $20.57 \pm 3.15$ & $22 \pm 3.87$ & $19.43 \pm 4.93$ & $20.17 \pm 2.4$ & $19 \pm 2.53$ & $19.33 \pm 3.2$ \\
\hline & Innovating & 15 & $21 \pm 2.9$ & $14.75 \pm 6.9$ & $15.5 \pm 1.91$ & $19.86 \pm 4.38$ & $22.29 \pm 2.98$ & $12.15 \pm 5.9$ & $19.5 \pm 3.27$ & $19.67 \pm 2.73$ & $19.33 \pm 2.34$ \\
\hline & Deceleration & 15 & $13.5 \pm 4.51$ & $9.5 \pm 2.08$ & $11.5 \pm 1.73$ & $11.57 \pm 5.16$ & $13.14 \pm 4.02$ & $9 \pm 5.57$ & $15.5 \pm 2.17$ & $15.33 \pm 4.03$ & $14.5 \pm 5.13$ \\
\hline & Retirement Planning & 15 & $12.5 \pm 5.8$ & $11.5 \pm 4.43$ & $12.75 \pm 1.26$ & $9.43 \pm 5.74$ & $8.86 \pm 3.72$ & $11 \pm 7.05$ & $13 \pm 6.9$ & $14.5 \pm 7.18$ & $13.83 \pm 7.41$ \\
\hline & Retirement Living & 15 & $16.5 \pm 7.85$ & $16.25 \pm 5.91$ & $14.5 \pm 3.32$ & $10.43 \pm 6$ & $11.71 \pm 7.2$ & $15.57 \pm 6.11$ & $16.17 \pm 6.77$ & $15.5 \pm 6.63$ & $14.5 \pm 6.66$ \\
\hline
\end{tabular}




\section{Intervention outcomes at an inter-group level}

The outcomes of the comparison between the three groups, in each assessement moment, are shown in Table 3. It indicates that the EG1, the EG2, and the CG, were equivalent, at the pre-test, in all the assessed dimensions. In what concerns to the post-test, there were statistically significant differences in the Holding $\left(X^{2}=6.95, p=.031\right)$, Updating $\left(X^{2}=6.29\right.$, $\mathrm{p}=.043)$, and Deceleration $\left(\mathrm{X}^{2}=6.04, \mathrm{p}=.049\right)$ subscales from the ACCI. The analysis of differences between the pairs of groups has clarified that these differences were particularly significant among the mean values of the EG1 and EG2 in the Holding ( $U=26, p=.024)$, and Updating ( $U=25, p=.042$ ) subscales, with higher levels of concern in the EG2, and also between the mean values of the EG1 and CG in the Holding $(\mathrm{U}=1, \mathrm{p}=.019)$ and Deceleration $(\mathrm{U}=1$, $\mathrm{p}=.019$ ) subscales, with higher levels of concern in the CG. Regarding to the follow-up, there weren't found statistically significant differences between the results obtained by each of the groups, in the addressed career exploration and career concern dimensions.

\section{Intervention outcomes at an intra-group level}

The comparison of the intervention effects in time, considering the results obtained by each group, in each assesment periods, indicated for the EG1, the existence of statistically significant differences, at the Extent of Self-Exploration $\left(\mathrm{X}^{2}=6.53, \mathrm{p}=.038\right)$, and the Amount of Acquired Information $\left(\mathrm{X}^{2}=6.5, \mathrm{p}=.039\right)$ subscales, of the CES, and the Stabilizing $\left(\mathrm{X}^{2}=6.5, \mathrm{p}=.039\right)$ and Consolidating $\left(\mathrm{X}^{2}=6, \mathrm{p}=.05\right)$ subscales of the ACCI. In what concerns to the EG2, it has been verified the existence of statistical evidence, to state that the levels of the Intended-Systematic Exploration subscale $\left(X^{2}=6, p=.05\right)$, as well as, the concern levels associated with Stabilizing $\left(\mathrm{X}^{2}=6.91, \mathrm{p}=.032\right)$ and Consolidating phases $\left(\mathrm{X}^{2}=7.58, \mathrm{p}=.023\right)$ differed between the three time periods. Also, in relation to the $\mathrm{CG}$, it has been proved the existence of statistical evidence to argue that the levels of the Internal Search Instrumentality $\left(\mathrm{X}^{2}=7, \mathrm{p}=.03\right)$ changed over the three moments. As it can be seen in Table 3 , the comparison between the pairs of moments, in each group, indicated, however, no statistically significant differences between the pre-test and post-test, the post-test and follow-up, and follow-up and pre-test, considering the critical value of significance of .0167 Bonferroni's correction. 
Table 3. Career Exploration and Career Concerns: intervention outcomes at an intra and inter-group level (n=18)

\begin{tabular}{|c|c|c|c|c|c|c|c|}
\hline \multirow{3}{*}{ Questionnaire } & \multirow{3}{*}{ Subscales } & \multicolumn{3}{|c|}{ Kruskal Wallis $-X^{2}(2)$} & \multicolumn{3}{|c|}{ Friedman } \\
\hline & & Pre-test & Pos-test & Follow-up & $\mathbf{X}^{2}(2)$ & $X^{2}(2)$ & $X^{2}(2)$ \\
\hline & & EG1, EG2, CG & EG1, EG2, CG & EG1, EG2, CG & EG1 & EG2 & $\mathbf{C G}$ \\
\hline \multirow{12}{*}{ CES } & Employment Outlook & 4.25 & 1.54 & 2.17 & 2.923 & .333 & 3.9 \\
\hline & Certainty of Outcomes & .022 & 1.81 & .857 & .182 & .75 & 3.5 \\
\hline & External Search Instrumentality & 1.96 & .315 & 1.87 & 2.286 & 2.48 & 4.95 \\
\hline & Internal Search Instrumentality & 1.24 & 1.08 & .69 & 4.5 & 5.41 & $7 *$ \\
\hline & Importance of Preferred Position & 3.42 & 2.45 & 3.67 & 3.5 & 2.24 & 1.37 \\
\hline & Extent of Environment Exploration & .148 & .845 & 2.42 & 1.714 & 3 & 4.1 \\
\hline & Extent of Self- Exploration & .117 & 4.95 & .696 & $6.533^{*}$ & 2.85 & 2.1 \\
\hline & Intended-Systematic Exploration & 4.83 & .226 & 2.51 & 5 & $6^{*}$ & .273 \\
\hline & Amount of Acquired Information & 5.32 & .533 & .855 & $6.5^{*}$ & .4 & 5.2 \\
\hline & Satisfaction with Information & 3.94 & 2.26 & 2.5 & 2.533 & 2.55 & 5.33 \\
\hline & Exploration Stress & .175 & .987 & .372 & 1.733 & 1.23 & 1.18 \\
\hline & Decision Stress & .046 & .7 & .491 & 1.2 & .222 & 1.24 \\
\hline \multirow{12}{*}{ ACCI } & Crystallization & .918 & 4.1 & 1.78 & 5.143 & .08 & 2 \\
\hline & Specification & 1.01 & 3.09 & .734 & 5.143 & 1.52 & 2 \\
\hline & Implementation & .028 & .978 & 1.24 & 3 & 1.85 & .636 \\
\hline & Stabilizing & 1.8 & 1.73 & 1.35 & $6.5^{*}$ & $6.91 *$ & 3.5 \\
\hline & Consolidating & 3.72 & 2.58 & 2.25 & $6^{*}$ & $7.58 *$ & 4.67 \\
\hline & Advancing & .41 & 1.59 & 4.31 & 1.733 & 3.92 & 3.39 \\
\hline & Holding & 2.15 & $6.95 *$ & .579 & 2.8 & 1.68 & 1.81 \\
\hline & Updating & .297 & $6.29 *$ & 4.03 & 3.5 & 2.35 & 2.33 \\
\hline & Innovating & .396 & 4.82 & 1.2 & 2.533 & 4.88 & .095 \\
\hline & Deceleration & 2.84 & $6.04 *$ & 2.79 & 3 & 2.15 & .667 \\
\hline & Retirement Planning & 1.64 & 2.78 & 1.77 & .000 & .095 & .471 \\
\hline & Retirement Living & 3.83 & 2.36 & 1.03 & .5 & 4.1 & 3.26 \\
\hline
\end{tabular}

${ }^{*} \mathrm{p} \leq .05 ; * * \mathrm{p} \leq .01 ; * * * \mathrm{p} \leq .001$ 


\section{Discussion and conclussion}

This study aimed to evaluate the outcomes of the CSMS in the participants' level of career exploration, and type of career concerns, using an intervention group, a comparison group, and a control group, assessed at three different moments in time.

Results show that, concerning the two experimental groups, the EG1 benefited most from the career self-management intervention model. Considering the three assessment moments, participants from this group present, at the end of the intervention, more intentional and systematic exploratory behaviour, directed to themselves, regarding, for example, their skills, interests, values, roles and lifestyle, as well as, a greater amount of information regarding themselves and the education, training, and professional world. In addition, this group also has lower levels of concern regarding the development of a proper lifestyle, characterized by satisfactory levels of autonomy, confidence, learning and development, as well as, lower levels of concern regarding obtaining security and stability in their professional contexts. As regards the EG2, its participation in the career intervention program, as well as, in the Seminar on Entrepreneurship (SENT), favoured the development of exploratory behaviours, in a more systematic and intentional way. However, it has also increased its levels of concern about the development of a lifestyle that comes close to the idealized, as well as, with getting a career path guided by issues of security and stability. A comparison between the results obtained by each of these groups, in different assessment moments, also indicates that participants from the EG2 have actually more concerns about the possibility of maintaining the status and position acquired in their profession, as well as, the need to stay in their current field of action. However, none of the performed statistical analysis could clarify the contribution of the SENT to the results obtained in the EG2. As it turns out, the experimental groups 1 and 2 have evolved differently among the three time periods considered, in particular regarding their concerns with the dimensions Maintaining, Updating, Stabilizing and Consolidating. However, it remains unclear to what extent these differences can be attributed to the frequency of SENT.

Considering these results, it is important to note that the CSMS contributed, in general, for an increase in the career exploration behaviors, but it does not seem to have had an impact on the participants' beliefs and reactions to the career exploration process. In addition, there 
was a significant increase in the self-exploration behaviors, but that was not accompanied by an increase in the environment exploration. However, literature in this area reinforces that these two types of exploration behaviors are distinct though interrelated, since that the way a person explores the academic and professional world is determined by the prior knowledge he/she has about his/herself; and, in turn, the self-knowledge will be strengthened by the world exploration, since the person confirm or disconfirm his/her personal and professional interests preferences (e.g., Rowold \& Staufenbiel, 2010; Stumpf, Colarelli \& Hartman, 1983; Taveira, 1997). Regarding the type of career concerns presented by the participants, at the end of the assessment process, taking into account their age, but also the phase they are living in terms of their $\mathrm{PhD}$, these results are consistent with what the literature refers to be the type of career concerns most appropriate for these participants (Super, 1990). However, it appears that, in the EG1, the intervention programs were effective in reducing the participants' concerns associated with maintaining their current lifestyle, as well as, the concerns related to the achievement of security and stability, while the EG2 obtained an opposite trend. It is possible to speculate that this difference may be due to the impact of the SENT, but it is also important to consider that participants' in the EG2, having an average time in the current functions considerably higher, are closer to a new career transition, which means they may be already demonstrating concerns about how will they keep their current life styles.

For the CG, during this assesment period, there was a positive development regarding participants' beliefs that the self-exploration could facilitate the achievement of their career goals, although this result registers a reduction in follow-up period. Compared with the EG1, participants in this group have higher concerns about the possibility of maintaining the status and position previously acquired in the context of their profession, as well as, higher concerns about the possible need to begin to reduce their role of $\mathrm{PhD}$ students. However, once again, it remains unclear what motivated, in the control group, an increase of their beliefs about Internal Instrumentality. These results are consistent with the obtained in other studies (e.g., Hirschi \& Lage, 2008), in which participants in the control group obtained favorable results in the dimensions assessed, although these participants were not involved in any intervention during the time period being considered. In this sense, it is only possible to speculate that the individuals' contact with their peers, members of the experimental groups, may be the cause of such results. 
Thus, these results lead to conclude about the effectiveness of the CSMS to work some of the career exploration and career concern dimensions, particularly in comparison with the non-intervention. These results are consistent with the literature in the area (e.g., Brown \& Krane, 2000; Whiston, Brecheisen \& Stephens, 2003) stressing that the career development and career management seminars, developed in a small group format, and with a brief and systematic nature, are the effective intervention modalities.

\section{Limitations}

It is necessary to deepen this line of research looking to fill some of the methodological constraints that have marked this study. On the one hand, regarding the sample, participants in the three groups are doctoral students in psychology, which themselves may already have started these career programs with a very high standard of career outcomes. For this reason, causing a strong impact on these results would be very difficult. It is also suggested that future studies cover a more diverse, in terms of participants' socio-demographic characteristics, to include students who are representative of different research areas.

On the other hand, and as regards to the assessment tools, they may not have been sensitive enough to detect the changes caused in the participants resulting from the seminars. Measures of career exploration, alongside with other measures such as decision-making and career concerns, are one option that may be very relevant to successfully determine the effectiveness of career interventions (Richard, 2005; Sopelsa, Taveira, \& Pinto, 2010; Whiston, 2000). However, in this particular case, the selected measures may have been inaccurate in assessing the impact of the SENT, suggesting the need for further exploration. Also, it would be important to analyze the effects of different assessment moments, particularly regarding the use of pre-test and follow-up moments (e.g., McLeod, 2003).

\section{Practical implications}

The current organizational world is guided by a set of periods of employment, interrupted by shorter or longer periods of unemployment. For this reason, it becomes increasingly important to encourage people to pursue entrepreneurial careers (Henderson \& Robertson, 1999). One of the strategies through which this incentive can be done is through a greater availability of career services and interventions that promote the exploration and reflection about different career paths, including more entrepreneurial paths. In general, people have very positive attitudes to entrepreneurship as a career alternative (Matlay, 2008). However, in 
practice, during a decision-making, entrepreneurship is not generally considered as a personal career alternative. In this sense, the participation in career management seminars, coupled with short courses and workshops on entrepreneurship education, may have an inspiring effect on young people, helping to spread the idea that entrepreneurship is a means by which to pursue and achieve different career choices, and that almost everyone can achieve their potential through as an entrepreneurial career.

\section{References}

Acs, Z. J. (2006). How is entrepreneurship good for economic growth? Innovations, 1 (1), 97107.

Appelbaum, S. H., Ayre, H., \& Shapiro, B. T. (2002). Career management in information technology: a case study. Career Development International, 7, 142-158.

Atkinson, C. (2002). Career managing and the changing psychological contract. Career Development International, 7, 14-23.

Baron, R. A. (1998). Cognitive mechanisms in entrepreneurship: Why and when entrepreneurs think differently than other people. Journal of Business Venturing, 13 (4), 275294.

Baron, R. A. (2004). The cognitive perspective: a valuable tool for answering entrepreneurship's basic "why” questions. Journal of Business Venturing, 19 (2), 221-239.

Baruch, Y. (2004). Transforming careers from linear to multidirectional career paths: organizational and individual perspective. Career Development International, 9, 58-73.

Benítez, J. T. M. \& Pérez, L. C. (2008). Behavior of university students with respect to developing their career. Electronic Journal of Research in Educational Psychology, 16 (3), 623-640.

Blustein, D. (2006). The psychology of working: a new perspective for career development, counseling, and public policy. Mahwah, NJ: Lawrence Erlbaum.

Brown, S. D., \& Krane, N. E. R. (2000). Four (or five) sessions and a cloud of dust: Old assumptions and new observations about career counseling. In S. D. Brown \& R. W. Lent (Eds.), Handbook of counseling psychology, 3rd ed. (pp. 740-766). New York: Wiley.

Bureau of Labor Statistics (2010). Number of jobs held, labor market activity, and earnings growth among younger baby boomers: results from more a longitudinal survey. Washington, D. C.: United States Department of Labor. http://www.bls.gov/news.release/pdf/nlsoy.pdf. Accessed 11 November 2011. 
Busenitz, L. W., West III, G. P., Shepherd, D., Nelson,T., Chandler, G. N. \& Zacharakis, A. (2003). Entrepreneurship research in emergence: Past trends and future directions. Journal of Management, 29 (3), 285-308.

Cappellen, T. \& Janssens, M. (2008). Career paths of global managers: towards future research. Journal of World Business, 40 (4), 348-360.

Carree, M. A. \& Thurik, A. R. (2003). The impact of entrepreneurship on economic growth. In Z. J. Acs \& D. B. Audresch (Eds.), Handbook of Entrepreneurship Research, (pp. 55-79). Dordrecht: Kluwer Academic Publishers.

Cooper, A. C. (2003). Entrepreneurship: The past, the present, the future. In Z. J. Acs \& D. B. Audresch (Eds.), Handbook of Entrepreneurship Research (pp. 21-53). Dordrecht: Kluwer Academic Publishers.

De Vos, A., Dewettinck, L., \& Buyens, D. (2009). The professional career on the right track: a study on the interaction between career self-management and organizational career management in explaining employee outcomes. European Journal of Work and Organizational Psychology, 18 (1), 55-80.

Duarte, M. E. (1999). Inventário de Preocupações da Carreira (IPC) [Adult Career Concerns Inventory (ACCI]. In M. Simões, M. Gonçalves, \& L. Almeida (Org.), Testes e provas psicológicas em Portugal [Psychological testing in Portugal] (pp. 49-60). Braga: SHO- Sistemas Humanos e Organizacionais.

Dutra, J. S., Veloso, E. F. E., Fischer, A. L., \& Nakata, L. E. (2009). As carreiras inteligentes e sua percepção pelo clima organizacional [Intelligent career and its perception by the organizational climate]. Revista Brasileira de Orientação Profissional, 10 (1), pp. 55-70.

Eurostat (2010). Europe in figures - Eurostat yearbook 2010. http://epp.eurostat.ec.europa.eu/portal/page/portal/publications/eurostat_yearbook_2 010. Accessed 28 September 2011.

Feldman, D. C. \& Bolino, M. C. (2000). Career patterns of the self-employed: career motivations and career outcomes. Journal of Small Business Management, 38, 53-67.

Gartner, W. B. (1989). “Who is an entrepreneur?” Is the wrong question. American Journal of Small Business, 12 (4), 11-32.

Gilbert, G. R., Sohi, R. S., \& McEachern, A. G. (2008). Measuring work preferences: a multidimensional tool to enhance career self-management. Career Development International, 13 (1), 56-78. 
Greenhaus, J. H., Callanan, G. A., \& Godshalk, V. M. (2010). Career management (4th ed.). Thousand Oaks: Sage Publications, Inc.

Henderson, R. \& Robertson, M. (1999). Who wants to be an entrepreneur? Young adult attitudes to entrepreneurship as a career. Career Development International, 5, 279-287.

Hirschi, A. \& Lage, D. (2008). Increasing the career choice readiness of young adolescentes: an evaluation study. International Journal for Educational and Vocational Guidance, $8,95-110$.

Högemann, J., Ribeiro, D., Oliveira, N., Costa, S., Pinto, J. C., \& Taveira, M. C. (2010). SelfCareer Management Intervention Needs: A Study with PhD Grant-Holders. Proceedings of the VI Career Development Conference. Braga: School of Psychology, University of Minho, 293-298.

Lucas, S. (2007). Developing competencies in university education: harmonizing with secondary education and the labor market, from social psychology view of education. Electronic Journal of Research in Educational Psychology, 11 (1), 125-158.

Martínez-Vicente, J. M. (2007). In this issue: Vocational and Career Guidance. Electronic Journal of Research in Educational Psychology, 11 (5), 1-4.

Matlay, H. (2008). The impact of entrepreneurship education on entrepreneurial outcomes. Journal of Small Business and Enterprise Development, 15, 382-396.

McKeown, T. \& Lindorff, M. (2011). The graduate job search process - a lesson in persistence rather than good career management? Education + Training, 53 (4), 310-320.

McLeod, J. (2003). Doing counselling research ( $\left.2^{\mathrm{a}} \mathrm{ed}\right)$. London: Sage Publications, Ltd.

Mitchell, R. K., Busenitz, L., Lant, T., McDougall, P. P., Morse, E. A. \& Smith, J. B. (2002). Toward a theory of entrepreneurial cognition: Rethinking the people side of entrepreneurship research, Entrepreneurship Theory and Practice, 27 (2), 93-104.

Murphy, S. E., \& Ensher, E. A. (2001). The role of mentoring support and self-management strategies on reported career outcomes. Journal of Career Development, 27 (4), 229246.

Neault, R. (2002). Thriving in the new millennium: career management in the changing world of work. Canadian Journal of Career Development, 1 (1), 11-21.

Organization for Economic Cooperation and Development (OECD) (2010). OECD, Paris. http://www.oecd.org/home/0,2987,en_2649_201185_1_1_1_1_1,00.html. Accessed 9 November 2011.

Peel, S. \& Inkson, K. (2004). Contracting and careers: choosing between self and organizational employment. Career Development International, 9, 542-558. 
Pinto, J. C. (2010). Gestão Pessoal da Carreira: estudo de um modelo de intervenção psicológica com bolseiros de investigação [Career self-management: study of a psychological intervention model with research grant-holders]. Unpublished doctoral dissertation. Braga: School of Psychology, University of Minho.

Pinto. J. C. \& Taveira, M. C. (2010). Seminário de gestão pessoal da carreira: avaliação de um programa de intervenção psicológica no ensino superior [Career selfmanagement: evaluation of a psychological intervention program in higher education]. Proceedings of the I International Seminar - Psychological contributes in educational contexts (pp. 96-212). Braga: School of Psychology, University of Minho.

Rafael, M. (2001). O modelo desenvolvimentista de avaliação e aconselhamento de carreira (C-DAC). Preocupações de carreira, crenças de carreira e stress profissional em adultos trabalhadores [The developmental model of career assessment and counseling (C-DAC). Career concerns, career beliefs, and professional stress in working adults]. Unpublished doctoral dissertation. Lisbon: School of Psychology and Educational Sciences, University of Lisbon.

Rafael, M. (2007). Career development and management in $21^{\text {st }}$ century adults: readings towards harmonization of global and individual levels. Electronic Journal of Research in Educational Psychology, 11 (1), 75-102.

Rauch, A. \& Frese, M. (2007a). Born to be an entrepreneur? Revisiting the personality approach to entrepreneurship. In J. R. Baum, M. Frese \& R. A. Baron (Eds.), The Psychology of Entrepreneurship (pp. 41-64). New Jersey: Lawrence Erlbaum Associates.

Rauch, A. \& Frese, M. (2007b). Let's put the person back into entrepreneurship research: A meta-analysis on the relationship between business owners' personality traits, business creation, and success', European Journal of Work and Organizational Psychology, 16 (4), 353- 385.

Richard, G. (2005). International Best Practices in Career Development: Review of the Literature. International Journal for Educational and Vocational Guidance, 5, 189-201.

Rowold, J. \& Staufenbiel, K. (2001). The validity of German version of the career exploration survey. International Journal for Educational and Vocational Guidance, 10 (1), 2134.

Salgado-Banda, H. (2007). Entrepreneurship and economic growth: An empirical analysis. Journal of Developmental Entrepreneurship, 12 (1), 3-29. 
Sánchez, J. C. (2011). Entrepreneurship as a legitimate field of knowledge. Psicothema, 23 (3), 427-432.

Sánchez, J. C., Carballo, T. \& Gutiérrez, A. (2011). The entrepreneur from a cognitive approach. Psicothema, 23 (3), 433-438.

Sarjoo, A. \& Barry, M.L. (2011). Towards a Career Management Framework for Civil Engineers in the South African Public Sector. Proceedings of the Technology Management in the Energy Smart World. Oregon, USA: Hilton Portland and Executive Tower, 1-9.

Silva, F. \& Taveira, M. C. (2010). Competências de exploração vocacional de adultos nãouniversitários [Career exploration competrences in non-university students]. In M. C. Taveira \& A. D. Silva, Desenvolvimento Vocacional, Avaliação e Intervenção ( pp. 183-196). Braga: Associação Portuguesa para o Desenvolvimento da Carreira.

Soares, A. P. (1998). Desenvolvimento vocacional de jovens e adultos: A exploração, a indecisão e o ajustamento vocacional em estudantes universitários [Vocational development in youth and adults: career exploration, indecision and adjustment in university students]. Unpublished master dissertation. Braga: School of Psychology, University of Minho.

Sopelsa, A., Taveira, M. C. \& Pinto, J. C. (2010). Abordagens ao Design Quasi-Experimental no Estudo da Eficácia da Intervenção Vocacional: Contributos Metodológicos [Approaches to the quasi-experimental design in the study of the vocational intervention effectiveness: methodological contributes]. Proceedings of the VI Career Development Conference (pp. 225-233). Braga: School of Psychology, University of Minho.

Stumpf, S. A., Colarelli, S. M., \& Hartman, K. (1983). Career Exploration Survey. Journal of Vocational Behavior, 22, 191-226.

Sturges, J., Conway, N., \& Liefooghe, A. (2008). What's the deal? An exploration of career management behaviour in Iceland. The International Journal of Human Resource Management, 19 (4), 752-768.

Sturges, J., Guest, D., Conway, N., \& Davey, K. M. (2002). A longitudinal study of the relationship between career management and organizational commitment among graduates in the first ten years at work. Journal of Organizational Career, 23, 731-748.

Super, D. E., Thompson, A. S., \& Lindeman, R. H. (1988). Adult Career Concerns Inventory: Manual for research and exploratory use in counseling. Palo Alto: Consulting Psychologists Press. 
Taveira, M. C. (1997). Exploração e desenvolvimento vocacional de jovens. Estudo sobre as relações entre a exploração, a identidade e a indecisão vocacional. [Youth exploration and career development. A study of the relations between career exploration, identity and indecision]. Unpublished doctoral dissertation. Braga: School of Psychology, University of Minho.

Ucbasaran, D., Westhead, P., \& Wright, M. (2008). Opportunity identification and pursuit: Does an entrepreneur's human capital matter? Small Business Economics, 30, 153 173.

Van Praag, C. \& Versloot, P. (2007). What is the value of entrepreneurship? A review of recent research. Small Business Economy, 29, 351-382.

Van Viannen, A. E. M., De Pater, I. E., \& Preenen, P. T. Y. (2008). Career management: taking control of the quality of work experiences. In J. A. Athanasou \& R. Esbroeck (Eds.), International Handbook of Career Guidance (pp. 283-301). Netherlands: Springer.

Whiston, S. C. (2000). Individual career counseling. In D. Luzzo (Ed.), Career counseling of college students. An empirical guide to strategies that work, (pp.137-157). American Psychology Association. Washington.

Whiston, S. C., Brecheisen, B. K., \& Stephens, J. (2003). Does treatment modality affect career counseling effectiveness? Journal of Vocational Behavior, 62, 390-410.

Wiklund, J., Davidsson, P., Audretsch, D. B. \& Karlsson, C. (2011). The future of entrepreneurship research. Entrepreneurship: Theory \& Practice, 35 (1), 1-9.

Wilson, F., Kickul, J., \& Marlin, D. (2007). Gender, entrepreneurial self-efficacy, and entrepreneurial career intentions: implications for entrepreneurship education. Entrepreneurship Theory and Practice, 31, 387-406. 